\title{
Crowds Management In Indonesian Football Event Case Study : Policing Management
}

\author{
Andry Wibowo \\ Pascasarjana Sekolah Tinggi Ilmu Kepolisian, Jakarta, Indonesia \\ wibowoandry1993@gmail.com
}

\begin{abstract}
Crowds become an important issue in policing research and practice. Crowds phenomena become a challenge for police management to make an order, safety and security in public issue. Crowds in football event bring some problems related to problem of order, safety and security and become a developing research object in football industry. This paper describe crowds problems in sport could transforms into identity problem. Problem orientated policing is a modern thought who give police to understand root of causes from social problem. This paper describe and explore condition from group of crowds Viking (Persib) and Jakmania (Persija) in Indonesia who have an identity conflict among them and have been distrubing public order, safety and security for almost to decade until now. Relate to those problems this paper also describe and explorw how Indonesian police management handle this problem as part of a policing models.
\end{abstract}

Keywords: crowds; incident drivent policing; identity conflict; problem oriented policing; crowds cycle 


\section{Introduction}

Crowds policing is the art of policing and characterized as important and evolutionary, adaptive, and contextual crowd based on historical perspectives, social milieu, crowds character and policy in the police organization. Evolutive characteristic is a basic function of the police force (Tamara.D. and Johannes Knutsson, 2011), policing of the crowds developed since the French revolution of 1799 and the birth of British policing initiated by Sir Robert Phill in the form of the Metropolitan Police Act, 1829 (in Braiden, 1992).

The militaristic approach to the crowds is gradually abandoned and is constantly changing through a more law-oriented approach to the prevailing laws of the country, including political and security policies. Le Bon's way of viewing the crowds as a frightening, dangerous, irrational, anonymous and violent entity can have a collective effect on the perspective of police organizations in the world until this day, beginning to get criticized, due to the implications of the militaristic approach by the police.

Critics of policing in the context of concept require governments, academics and police organizations endorsement to do research in various phenomena of crowds in many social perspectives. The researches have influenced and encouraged by police organizations around the world to change the approach to see crowd's management to be more adaptive and contextual based on the characters possessed by the crowds that they are (according to Canetti, 1973) metamorphose and possess the power which is not always converted to be a threat.

Crowds phenomenon is part of the daily portrait of society in various forms, activities, and problems. Crowds can be viewed in heterogeneous and homogeneous characters. Policing on football's fanatical conflicts in this study (Viking and Jakmania conflicts) was chosen because the conflict was one of the social problems that affected social order, security and safety and had not found yet a solution for those conflicts.

Le Bon's perspective on today remains dominantly used when the Police are confronted with Persib and Persija crowds in their matches. The anxiety that existed in the Police influenced decision-making related to the location of the match and the prohibition of the presence of one of the supporters. The study found that there has been a transformation or metamorphosis of conflict in sport's events into identity conflicts. The triangulation analysis, Police, Viking and Jakmania through the analytical approach (Brown, 2011) to prove that prejudice (negative) has occurred reciprocally between Police - Viking Jakmania.

This identity conflict has implications like widespread conflict that becomes unpredictable, done by anyone, anytime and anywhere. I compared the phenomena of hooliganism in Europe that have been crystallized and easily classified, but 'hooliganism' in Indonesia became the opposite, because hooliganism's values in Indonesia has become a general belief for the community.

Thus, the concept of preventionoriented policing that has been used as a conceptual formula for security planning is ineffective and efficient in resolving conflicts of identity's issues and creating a cycle of conflict between Vikings and Jakmania. This study offers alternative policing art using the 
problem-oriented policing paradigm that according to (Goldstein, 1979) The police must be able to resolve the root of causes of this problem.

\section{Literature Review \\ Viking and Jakmania Group Identity Formation}

As a synthetic identity (John Voris, 2015) Viking is a metamorphosis of bobotoh which became a common icon of Persib supporters, also as a symbol rather than continuation of the greatness of the Pajajaran Kingdom.

The naming of the Vikings is the imagination of Ayi Beutik, on the values of the Vikings existing in Scandinavia. In contrast, Jakmania is a popular naming that is used to attract members as much as possible, supported by Gugun Gondun and Governor Sutiyoso. The characteristics of poor people in Jakarta are also represented in the form of Jakmania as illustrated by (Clarke McPhill, 1997) which could be formation of the Jakmania's crowd formed by lower-class society. This view as a stereotype not recognized by sociologists (Charlcouch, 1998 in Kenny M. John 2001).

Jakmania and Viking can be looked as a group of supporters who fall into the category of synthetic identity certainly and they are having the same sub and different cultures. The similarity is in good and bad supporters, the spirit of raising the club and regionalism, through the principle of conquering and awakening. Then explores society as the social capital of identity (Castlle, 2000).

Use of symbolic symbols of violence on the club's symbolic or supporters. Persija uses the meaning of "Kemayoran Tiger" as an imaginary value of supporters and Vikings, using the Viking imagination as an elementary value of the supporters. Exploratory and expansive characters, both natural and fabrication, occur in the growth of Jakmania and Viking.

The growth of Viking and Jakmania is in line with the development of football as an industry, coherent with the number of football fans as the most popular sport in Indonesia. Family, peers, mass media, social media and club achievements is the trigger for increasing number of member of Jakmania and Vikings.

Originally, members of one area, and one ethnic group, flourished into different regions and into various ethnic groups. The influence of social media, as part of the information revolution (see Castle 2000) also enriches the positive and negative characters of Jakmania and Viking.

In the case of crowd's theory (Le Bon, 1896) and (Canetti, 1973) both have similarities in processing, always growing in goal achievement (Canetti, 1973), and irrational values of violence seen by criminogenic factors for apparatus Police (Le Bon, 1896). In the perspective of the second relation, the Vikings against Jakmania, or vice versa, have a dual theoretical perspective. Jakmania and Viking, look into the self-looking as a unity that has solidity and solidarity, thus transforming into power (see Canetti, 1973).

In contrast, Jakmania sees Vikings or reciprocally, as a rivalry of Jakmania's existence as well as Viking as something monstrous. (see Le Bon, 1896). Reflecting from the history of its formation, Jakmania and Viking have a different picture.

Viking is a Persib supporters who have been born first with a background of love for Persib. It can be said 
that the identity formed is more cultural and decreases. The love of tribal base in West Java further strengthens the Viking itself.

The holliganistic nature that began to enter Viking values early on made a lot of behavioral influences when they are in the stadium. This condition is always in reproduction of discourse of figure and the figure that is admired as a protector (Ayi Beutik) further strengthens the values that exist in the Viking.

Hooliganism practices that are considered proud / cool / militant into a culture that continues to form Viking. Solidarity of the power of the period also formed. Not infrequently West Java politicians take advantage of $\mathrm{Vi}$ kings in the campaign to attract more votes.

In essence this condition is a good condition in a community. The community will continue to hold the value of culture and togetherness in establishing various activities. Together Persib and West Java community put together and form a new community entity. As a cultural binder, this condition is also vulnerable to polluted inappropriate understanding. Such an example is hostility to Jakmania that continues to be produced without finding a way out from the conflict or conflict without ending which is characteristic of a cultural-based conflict based on history and identity.

Another of the Vikings, Jakmania itself has a more dynamic identity. Many factors influence this condition. First, Jakarta as a city whose population is multicultural causes the value of being adopted is not uniform. Second, the impure formation of Jakmania comes from below. There are interventions from the management and Gover- nor Sutiyoso. Bung Ferry which is a figure who admired Jakmania was born in Bandung and originally was The Commandos (Pelita Jaya Fans). This condition affects the stronger values that exist within the Vikings than in Jakmania. The value of militancy and holiganism adopted will be more rooted than Jakmania.

Associated with conflicts involving both Vikings will further decrease. This condition is evidenced by the explanation of one of the Vikings that use the nuanced attribute of SARA "let this Enmity Stay Eternal" "Jak is Dog". X as informant (informant does not want to be named), he thinks he uses the attribute just to practice what Ayi Beutik used to say. Ayi Beutik as a figure who respects the Viking be binding cultural identity other than the Sundanese tribe of the majority of the population of West Java.

From the phenomenon of $\mathrm{Vi}$ king and Jakmania there are groups of Viking Border and Jakmania. The character of the border region which is a Viking that often conflict with Jakmania in its territory. Daily from the region is often colored by conflict. This group is also in the Viking conflict and Jakmania that often-reached violence for Jakmania group. Viking borders continue to reproduce existing conflicts with Jakmania. The settlement of the prejudices arising from Viking perspective on unfinished borders will continue to be a conflict even beyond the stadium.

The last case that is still warm is the case of beating of Ricko (Viking) by the Viking border that strikes Ricko as Jakmania in the game in July 22, 2017. In the context of Jakmania, there is a group called Rojali, which is the main cause of Jakmania involvement in 
various conflicts including Vikings. Jakmania Central Board admitted difficulty in handling this group. The claim of the Chairman of the Central Committee of Jakmania felt that they (Rojali) were not part of Jakmania. To anticipate the widespread influence of Rojali, PP Jakmania formed various campaigns one of the 7 characteristics of Jakmania.

The destructive behavior of vandalism and anarchy from Rojali is one of the causes of the reproduction of the conflict, especially with Viking. In the context of a conflict involving Jakmania's organizational supporters, Jakmania puts "rojali" as a scapegoat without understanding the root cause of the conflict itself.

Characteristics of spectators from the matches between Persib and Jakmania can be identified depending on the location of the game held. In the match in Bandung, it was obvious that the Vikings who attended the match at the GBLA stadium were very disorganized. This is due to several reasons, the first factor of crowd's management and crowd's control (see Je'anna, 2001) does not work.

Parking irregularities, passage of bottles entering the stadium, dense road access to and exit of the stadium, to ineffective plotting of security forces. The result of this irregularity is the casualties of the Vikings who become victims of the misdirection. This became a paradox when previously Kapolrestabes Bandung City has given a ban to Jakmania to attend the GBLA Stadium but chaos still happened.

This condition is also encouraged by the disappointment of Bobotoh over the course of the game, so the Bobotoh in which there is also a viking that defines the crowds acting irration- ally because of a driving factor (Le Bon, 1896).

This incident also resulted in one policeman from the provost unit injured in his nose hit by a throw. It can be said in the theory of crowds according to (Le Bon, 1896) life is the transformation of though. In theory (Canetti, 1973), crowds and transformation of power suggest crowds have the ability to influence and be influenced in positions as objects or subjects. In this context soccer players can be said to be crowds that in popular terms of football, audiences are referred to as the twelfth player.

On the other hand, this phenomenon still proves that the concept of prejudice (Brown, 2011) is still held by the Vikings, although the guidance is clear but they still feel that Jakmania will be present, and when Jakmania is present, will be a means of venturing their grudge against Jakmania. This is evident when the perpetrators of the beatings were arrested, he explained the motive is hatred against Jakmania. If crowd management has a good and well -organized mechanism, that case can be avoided (Berlonghi, 1994).

Crowd control focuses on actions taken to organize crowds as they have led to behaviors that lead to disorders of security and order (Berlonghi, 1994). An interesting feature of the Viking characteristics that lead to the GBLA stadium is the variety of processes used. In this assembling process (see Kenny M. John, 2001) some of the Vikings departed were coordinated by their respective districts.

However, some are using access by changing the vehicle many times. Success in this assembling process should be accompanied by a gathering process that relates to crowd's manage- 
ment at GBLA Stadium (Je'anna L.A., 2001). Of the Vikings present, dominated by young men, in addition to the access that is difficult to reach, a great risk to attend children and women.

In contrast to the characteristics that occur in Solo. Previous match Persija vs Persib should be held in Bekasi and the match does not get permission and must be transferred to Solo by Persija management because of security's consideration, because on the same day there will be a demonstration in Jakarta. The security action will not take risks by presenting two big masses whose risks are in direct clashes.

The transfer of the venue became controversial because it happened in a fast tempo. Counted within three days of the match decision in Bekasi canceled and had to move to Solo.

Indonesia's FA Official (Panpel) made some effort to make this in very fast preparation. Solo is chosen because of the cooperation between panpel Persija with local panpel from Persis Solo. There are different things from the game in Solo, namely silahturahmi (Meet up) before the game. This gathering is done by Kabag. Ops Polresta Surakarta to minimize the friction and ask for cooperation between Pasoepati with Jakmania to secure the match.

Police efforts always to maintain security by appealing to local famous liquor in Solo. It aims to strengthen the coordination related to Solo conditions and the preparation that needs to be done (see Parks, et, at., 1981). Counted tickets amounted to 17,250 tickets which is the result of ticket sales for 4 Days.

The establishment of Jakmania's organization in this context succeeds in mobilizing mass in large numbers in the preparation of a short time. This assembling process (see Kenny M. John, 2001) gets escort or crowds control form for Jakmania entourage (Berlonghi, 1994).

This process is done with a form of cooperation between the Polda Metro Jaya, Polda Jabar, Central Java Police who escort a relay. To secure this process also needs to be done communication process between Police and society. Communication formed between the police and the community is quite effective where awaken mutual trust (see Parks, et, at., 1981). A similar process is done when traveling back from Solo to Jakarta or dispersal process (Kenny M. John, 2001). Jakmania entourage first arrived in Solo at 02.00 am, they were dominated by a group of 17-25 year old boys who will be channeled in the velodrome area at Manahan Stadium.

This canalization aims to anticipate the irregularities that will occur in Solo. The small Solo area will have 17,250 people who coming from Jakarta and if not done a good crowds management process will be a big potential to be a riot (Berlonghi, 1994). Securing Action should be strengthened by crowds control (Berlonghi, 1994) conducted by Surakarta Police by inspecting Jakmania entourage who arrived in Solo. This inspection resulted in a group of supporters who were caught possessing or consuming liquor. The perpetrator was held in Surakarta Police until the match was over.

A similar phenomenon that occurs in Bandung and also occurs in Solo is the action of raiding the opposing supporters who are identified not part of those supporters. Counted 6 times assault by Jakmania to groups identified as Vikings. This action is not only 
triggered by prejudice as happened in Bandung (Brown, 2011).

However, it was also triggered by conditions on the ground (see Berlonghi 1994) of a disastrous match against Persib, from Kim Kurniawan's injury, a disallowing a goal, until a penalty decision would easily identify those who looked disappointed. Patterns that occur from the 6 events are the same, cell phone checks to look for evidence and proved as a Viking then continued by brutal cation from them.

\section{Research Methodology}

This research using qualitative approach as a method in study case on conflict Viking and Jakmania supporters who always support both Persib and Persija football matches for this past five years.

Data collection techniques I used are; in-depth interviews, direct observation, focus discussion groups, expert panel discussions, and document studies over the past five years research which correlated with this topic.

From the process of findings of the field of case, analyzed by several existing libraries, the research finally revealed that crowds policing or policing of the crowd by Polrestabes Bandung and Polresta Surakarta's used paradigm through power blocking mechanism as an effective policing art in handling crowds.

\section{Result And Discussion \\ Metamorphosis Viking and Jak- mania Conflicts}

To understand the conflict between Viking and Jakmania as a rivalry of Persib and Persija begins with the understanding that football is a tool of struggle of the Indonesian nation's identity against the colonial. From that his- tory, football in Indonesia is a legacy sport from colonial culture (transnational sport) introduced by the Dutch. Not known yet where is the term football's supporters came from. There are clubs and players. Football also became a portrait of social class (indigenous, non-indigenous and Dutch).

It shows that since the birth of football in Indonesia, the values of social segregation, based on ethnicity (Dutch, Chinese, and Native) have grown as differentiators between clubs.

For the Natives (Indonesia) the emergence of football clubs, BIVB, and other club clubs based on the name of the region, is a manifestation of the attitude of Indonesian nationalism, to show a sense of coincidence with the clubs supported by the Dutch. This shows the character of the egalitarian concept (Anerson Richard, 2002) which is shown by Indonesians (indigenous). From that construction then the Japanese colonial saw that football club formed by the Indonesian (indigenous), as a medium in showing identity "keIndonesiaan," as well as a symbol of resistance.

As the result of the concept of colonialism (relations of domination) colonial nation and colonized nation potentially to be very dangerous for the Japanese nation. The Indonesian football club was frozen by colonial nation. From the description, Persib Bandung as team's pride of citizens of Bandung, especially among Sundanese in the era of independence is also a symbol of continuity or symbolic metamorphosis of the kingdom Pajajaran. Simultaneously, forming a new sub-culture of identity of a delay or identity " $\mathrm{Ke}-\mathrm{Pa}$ jajaran-an".

Persib can be said is a symbol 
of the new identity formed in the Sundanese society. When speaking about Persib, synonymous with Sundanese culture (see Jen Phiney, 2001). However, in terms of membership bobotoh not limited in Bandung or western Java. Although Persib is headquartered in Bandung, but supporter bobotoh spread in West Java, ranging from Banjar, Ciamis, Tasikmalaya, Bogor, Cirebon, Kuningan, Karawang, to Bekasi. Bobotoh also located outside the Province of West Java, such as Jakarta, Tangerang, and Serang.

This becomes widespread according to the characteristics of an identity according to (Utami, 2011). In the virtual world, fans are also monitored there are settlers abroad such as Malaysia, Singapore, Saudi Arabia, United Kingdom, United States, and others. The role of media as identity formers also encourages how identity is formed (Effendi, 2011).

As (Castlle, 2000) states that humans are passing through the industrial age to the information age. With the era of globalization and communication and information technology, (Castlle, 2000) states will give birth to a new social network, industry and culture. This also happens to Jakmania and Viking soccer supporters, where the virtual world becomes the arena of communication, constituency (rivalry) at the same time, hostility. This is worsened by the capitalization of Jakmania and Viking conflicts through online and medsos media. Bobotoh mostly comes from Cianjur with 637,263 people, Garut with 627,240 inhabitants, Bandung in third place with 506,774 inhabitants, fourth is Jakarta with 260,056 people, and Bobotoh in Surabaya is in fifth position with 93,965 inhabitants.

Based on data by PT. UN, of 5.3 million Bobotoh in western Java, 26 percent are women. Approximately 1.378.000 female Bobotoh have demography, which ranged from $21-40$ years old, especially married and tendency to like Persib due to influence of husband and child (Djuhaer, 2003).

Bobotoh will always meet the stadium, either if Persib compete in Bandung or Jakarta, with its attributes. Bobotoh also performs a joint watching in front of the television for those who can not go to another city if Persib perform away games as a form of commitment (Utami, 2011). The bobotoh in general have two major groups namely, Viking Persib Fans Club and Bobotoh Bandung Maung Bersatu (The Bomber). There are also bobotoh types based on the characteristics, there are at least Ultras Bandung, Flower City Casuals, Bobotoh Oriental, and Bobotoh Singapore (Wikipedia).

The reality of the rise of football's supporters in line with the era of national football competition as part of the national development in the field of sports during the New Order era, which is still amateur competition or interregional. Then as the crowds theory (Canettti, 1973) told us that crowds is a process of bobotoh development also shows, coherence to the theory. Where bobotoh, grown in various regions in West Java.

In facts the development in other areas, inside and outside the country. The number was from dozens transformed into hundreds to thousands and even millions. Bobotoh is an imagine community (Anderson, 1983), which is based on values to Sundaan in line with Persib. According to (John Voris, 2015) bobotoh can be categorized as a synthetic identity from the Sundaan. As part of Bobotoh, there is a group of 
Yandi (supporter) called Viking Persib Fans Club. Viking can be identified as the synthetic identity of bobotoh which indicates the strength of trans culture or mix culture that influences the authentic culture of the Sundanese (John Voris, 2015). It also co-stars with football as an imitation culture from European football's origin culture. From this naming, multiculturalism in soccer support proved to exist, the first being that bobotoh as the parent of the synthetic culture of delays metamorphosed naturally into several other support groups (see Canetti, 1973).

When they are naming the group they imagination came from portraits of supporters in Europe, such as Italian ultras, FCC of England, Vikings such as Scandinavia and oriental show Asian identity. It also shows social and class segregation not only in football clubs in colonial, but also in football supporters in the era of development in Soeharto Era. This means that social segregation is the background of (SARA) that gave birth to synthetic identity naturally or through fabrication, always growing in society (John Voris, 2015).

Viking is a symbol of conquering which is the product of Ayi Beutik Suparman's imagination of the legendary name of a powerful nation in Scandinavia, which has the values of a strong, savage, brave, unyielding and inviting nation. Although, Viking is a metamorphosis of bobotoh, because of its natural nature, the Vikings do not recognize the semi-bureaucratic organizing system.

Like the crowds, Viking also develops naturally (see Canetti, 1973), through the hereditary mechanisms of the family (Stuart Hauser, 2001). Viking also develops to other areas, no longer confined to the Cibangkong and Pasirluyu regions, as the Viking homebirth. As a naturally formed society, the Vikings also remain familiar with group values, as the requirement of an identity, which I call Vikingnisme.

Values experiencing acculturation between Vikings as imagine norms derived from Vikings in Scandinavia, procrastination as part of bobotoh Persib, loyalty (loyalty to the group), solidarity (faithful friend), and values in urban society (style or style) symbols, authentic identities brought from the birth of each individual and social environment, where he lives. The growing number of Vikings, also boosts business growth related to accessories and attributes of football supporters. That supporters also have an important role in an economic activity, especially the football industry.

In the Viking group, there are symbolic figures that influence the Viking development up to now. The figure is Ayi Beutik, who can be said as the central figure in the archipelago (General Soedirman for the military, Sukarno for Marhen nationalists, or RA Kartini for women's emancipation in Indonesia).

Ayi Beutik is the founder and patron of the entire sub culture of the Viking members. He was a charismatic figure who provided the first normative fundamentals of the Vikings. His boldness became the most basic reference value of Viking members. As a leader, of a group of natural and cultural nature, willing to sacrifice for other members who make themselves very much in love with the Viking group and other supporters who wing "hard".

As a natural and cultural group, the leadership character of Ayi Beutik becomes the main magnet affecting the 
rapid growth of Viking members, not only in Bandung, West Java and other areas (see Canetti, 1973). If the analogy, with the process of formation of butterflies, it can be said Ayi Beutik is a determinant factor of the Viking metamorphosis process (see Canetti, 1973).

Even if we imagine the Vikings are a group of beliefs, then in VIking is also born, rituals that distinguish between Viking members and other bobotoh. Ayi Beutik becomes the object of a ritual for Viking members who are believed to be able to give "strength" in the form of courage. On the other hand, Persija as a club born since the colonial era, same with Persib Bandung. Persija previously named VIJ, is a symbol of the existence of indigenous peoples (betawi). As a symbol of the spirit of equality and resistance to colonial symbols and class distinctions (VBO) as the Dutch formation.

The difference with Persib, that Persija originally named VIJ, has had a group of fans or fans known as VIJers. Post-independence Persija and Persib is one of the founding initiators of PSSI. Persija, named itself as "Kemayoran Tiger" which has the meaning of a beast imaginable as the King of Forest, which has the characteristics of ferocious, brave, in respect, and the ruler. This is reinforced by the use of red on club uniforms.

The existence of Persija in Jakarta which is a symbol of a metropolitan city, whose population is multicultural, until 1994 or the Indonesian league is a club that does not have many fans and this is indicated by the lack of audience. This then affects the club's internal conditions. This situation encourages the role of DKI Jakarta local government, to intervene to help Persija as the club pride of the capital.
From this can be interpreted, that Persi$\mathrm{ja}$ is a club that has historical value, in the dynamics of Indonesia, the symbol of the pride of the capital, both society, and government.

Jakmania is a group of supporters whose development is heavily influenced by bureaucratic policy, but this is in line with the common concern among Jakarta youth who enjoy watching Persija with Jakarta Capital City government and management under the leadership of Governor Sutiyoso for the lack of spectators at Persija Jakarta compete. This feeling of alienation and marginalization is a major consideration of Jakmania's establishment as a new synthetic identity (John Voris, 2015).

This formation is different from the pattern that occurred in Viking. If Viking is based on natural, bottom-up, fluid, cultural values, although familiar with simple organizational systems, the Vikings are a continuation of the greatness of the Pajajaran kingdom (Persib).

In contrast, Jakmania is a tool or instrument fabricated through the collaboration of the provincial government and the will of the children of Jakarta. The underlying spirit of Jakmania's presence is the resurrection values of the people of Jakarta, to be the hosts in their own region. From such a pattern, Jakmania tends to be formed based on the norms of forming a community organization, one of which has $\mathrm{AD} /$ ART. Recruitment involves the village, to socialize as well as encourage the local people to watch the game conducted by Persija Jakarta.

Nevertheless, the crystal crowds of Jakmania, numbering 40 people, became a community group that invites the people of Jakarta to join Jakmania which is the nature of the identity of the 
exploration (Utami, 2011). In addition, Gugun Gondrong as icon Jakmania is an artist so his popularity becomes a magnet to attract new members (Hamley, 2001).

As a synthetic identity of a new group, Jakmania members are bound by the rules, which are mentioned by $\mathrm{AD} /$ ART. From the beginning Jakmania in the form, in support of the development of club Persija from the social and economic (ticket entry, merchandise, etc.). As the early history of football in Indonesia as a means of identity struggle against the colonial, Viking and Jakmania relations as part of Persib and Persija rivalitas cannot be separated

\section{Transformation in Sport Event Conflict to Identity Conflict}
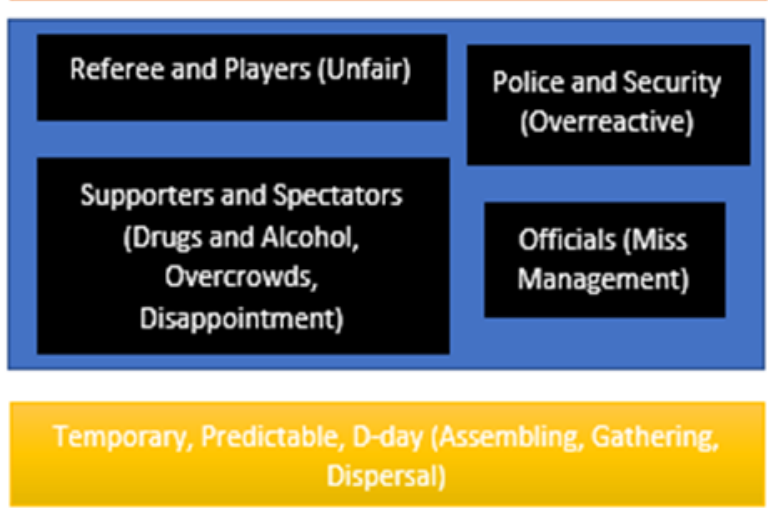

from the form of harmony metamorphosis relation to a relationship that is conflict.

In the history of their relation, they can be described as follows; First, the crowd at the Silwangi Stadium was influenced by the situation of the matches, the emotion of the audience was strongly appreciated by the field conditions of the match where Persib suffered a defeat from Persija (Berlonghi, 1994). Second, the failure of crowd's management process built by Persija and Jakmania and crowds control operated by the Police on the agenda of the away match to Siliwangi Stadium. This failure can be identified

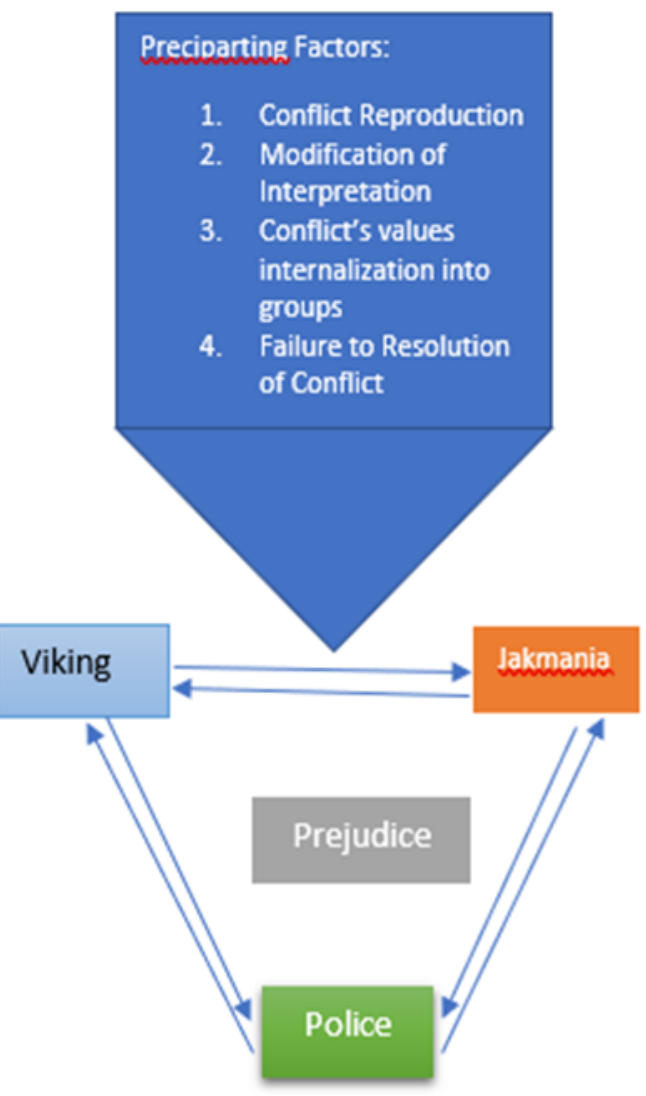

Figure 1. Transformation in sport even conflict to identity conflict 
through the crowds stage of (Kenny M. John, 2001).

At the assebling stage there was a miscalculation of the data from the quota of 400 people to 1000 people. This condition influences the next process of gathering at Siliwangi Stadium, the capacity of the stadium is not big with the match allocation of the tickets with the number of spectators in attendance, resulting in mass accumulation outside the stadium.

From this mass buildup there was a clash between the Vikings and Jakmania. In the process of diseprsal also influential, where Jakmania entourage who will return to Jakarta, involved clash with Viking. From the description, it can be interpreted that the police and match management is not ready in the face of overcrowding situation. In this context crowd's management and crowds control (see Berlonghi, 1994) play an important role in anticipating conflicts in the crowd's agenda. Third, the emergence of a prejudice (Brown, 2011).

This prejudice arises after the events that occurred at the Siliwangi Stadium. Jakmania feels to be a disadvantaged party because in the agenda to attend the away match is not in line with expectations. This action was responded by beatings to a group of $\mathrm{Vi}$ kings who attended a quiz show at one of the TV stations in Jakarta. This conflict is repeated and reproduced by the Vikings as well as Jakmania, the basis of the reproduction of this conflict is the prejudice that gave rise to a stereo-

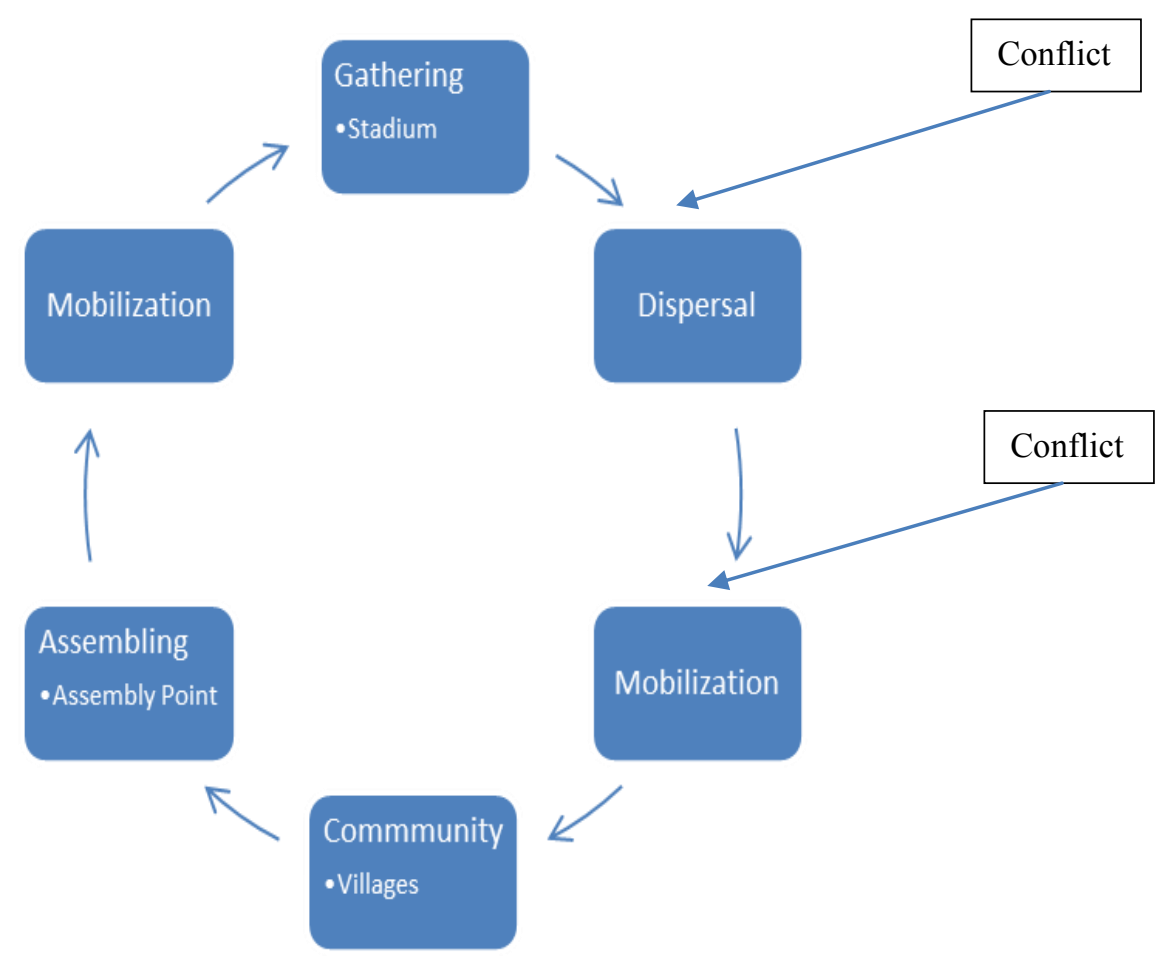

Figure 2. Conflict Point in Sport Event's Conflict 
type (Sear, et al. 1994).

Of the three factors the conflict began to happen, when Persija supporters who came to Siliwangi Stadium in 2000, experienced violence by supporters Persib (Viking). Then, there was an act of revenge by supporters Persija (Jakmania) against Viking at Indosiar tv station on the show Quiz Who Dare. As Herbert Blumer (in Sunarto, 2000) that humans act on the meaning that others give them. This means that in the event Viking treatment at Siliwangi Stadium rewarded by Jakmania in Indosiar.

In this case also reflected the existence of conflict metamorphosis. After that, conflicts continue, involving Vikings and Jakmania, during matches and out of football matches. This illustrates a conflict metamorphosis. From football matches as precipating factor examples, poor crowd management (see Berlonghi, 1994) to conflicts related to group identity, which can happen anytime and anywhere (Figure 1).

Conflicts are aggravated by the interpretation or interpretation of the cases, by both parties, either through interaction with the direct victims / perpetrators and the result of the interpretation modifications made by Jakmania and Viking members (Herbert Blumer in Sunarto, 2000).

This extends with the increasing number of Jakmania and Viking members and the use of social media (see Castells, 2000). Then, protracted conflict and the modification of the interpretation of each of the sides that resulted in the acute (Brown, 2011) prejudice not only to individuals involved in the conflict but extends to group members is generative or hereditary.

In Figure 1 it is illustrated that in this context there is a common con- flict transformation in football towards, an identity conflict. The transformation of this conflict also shifts the conflict point between the two. Here is a difference of conflict points that occur from sport event conflict to identity conflict (Figure 2).

\section{Genesis-Based Policing as a Model of Current Police Policing}

In the international context, policing the crowds have not yet been found explicit and explicit operational definitions, but in the same study of crowds in sport event management some literature introduces what are called crowds management and crowds control (Berlonghi 1994 and Je'anna 2001).

Crowds management talks about the conduct of football matches conducted by event organizers. Crowds control talks about the role of police in a sporting event that is how police deal with potential security problems caused by crowds through high and low policing and soft and hard policing approaches.

In the context of Indonesia, of course, crowds policing is an important thing to formulate its operational definition, considering that as a country that has a large population, crowd's phenomenon is a phenomenon that becomes a picture of everyday life, including crowds in sports, especially in the field of football.

In managing the policing model in an event a football game needs to understand how the Police view handles this against soccer supporters (Chysnanda, 2011). Basically, the policing done will aim at a regular society 
(Kari Sari, 2014). In this context, the police's view of society is an important factor.

What happened in Bandung and Solo is a form of incident driven policing (Weisburd, et.al., 2008) that tried to anticipate the existence of matches at that time. This anticipation in the background of the existence of a similar phenomenon in the past. The banning of one of the supporters into the game is a real, unfinished policy of a security system which focuses only on the day's matches.

Both in Bandung and Solo, the security policing model through the power blocking security approach of personnel formed using the ring oriented tactical model (see Tony Narr.et.al., 2006). Differences occur if in Bandung led directly by Kapolrestabes Bandung in Solo under the direction Kabag. Ops Polresta Surakarta.

This happens because of the different experiences of Kabag Ops Polresta Surakarta has experienced in handling soccer crowds. In this context both still do not solve the conflict problems of these supporters. If it refers to the concept (Goldstein, 1979) then the police should be able to penetrate the security by using a problem oriented policing approach.

The influence of incident driven policing (Weisburd, et.al., 2009) is the accumulation of the number of personnel (power blocking security personnel) in both Bandung and Solo. This buildup comes from a similar case experience that will address the "do not take for granted" views. This will make the decision not efficient in terms of personnel and security budget. The Renpam also wants to show that there are socalled professionalism organization characterized by competence and divi- sion of labor (Rietzer, 2009).

In Sociology, (Parsons, 1975) the division of structures in accordance with the functions and tasks. Still the actions of personnel coming out of the Security Plan, indicating weak supervision and lack of awareness of functions and tasks. In accordance with three key aspects in the definition of control, as well as a plan is control. In the view of researchers, the situation of football matches is a part of an inseparable crowd, even though it is a watched object.

The football game itself has been hypnotized from crowds that greatly affect the sentiment and action of the audience, as it was said (Le Bon, 1896) that crowds are contagion. Incident driven policing with the use of power blocking security's personnel (see Tony Narr.et.al., 2006), is a form of the acute (Brown, 2011) prejudice to triangular conflict relationships between Vikings, Jakmania and Police. In other word, according to (Blumer, in Sunarto, 2000) the presence of Viking and Jakmania in Persib and Persija match is understood by the Police as a high-risk match which has the potential of riots, commodity riots (looting, vandalism) and communal riots (identity conflicts against other groups).

Incident driven policing demonstrates that crowd's management and crowds control in the match security system are reactive, temporary and do not touch out-of-game conflicts or root of causes from Viking and Jakmania conflicts. In the match Persib and Persija crowds policing that occurs affected by anxiety.

In perspective (Canetti, 1973) this approach gathers as much strength as possible to reduce the anxiety that occurs to the police. In addressing the 
issue of Police Management (Tony Narr., 2006) police have carried out these three issues.

In this context it means the police are able to maintain physical security, but not touch the psychic side. In the security scheme, the police are more focused on the gathering stage, because the Jakmania and Viking conflicts have crystallized then the current paradigm should develop with the aim of resolving conflicts to ensure security. The police are obliged to establish order in order to ensure security.

\section{Policing in The Crowd's Cycle at Persib and Persija's Football Match-} es

The finding in this research is; the crowds cycle on Viking and Jakmania, which became the basis of crowds in Persib and Persija matches. This discovery differs from the point of view (Kenny M. John, 2001), which crowds as assembling, gathering and dispersal processes.

The crowds cycle can also explain that individuals, groups and crowds, are different from (Le Bon, 1896) which only describes individuals to crowds. Including anonymity understanding of crowds of soccer supporters does not occur when fans present their group identity. In observing the match Persib and Persija both in the context of matches in Bandung and Solo then the researchers tried to formulate how the role of the policing that occurred related in handling crowds. Can be seen in Figure 3.

Through this picture researchers see that there is a process of how crowds in doing activities, especially in the agenda to watch football games. In the theoretical sense before the crowds are viewed as a process (see Kenny $\mathrm{M}$. John, 2001). T

he researcher made a renewal

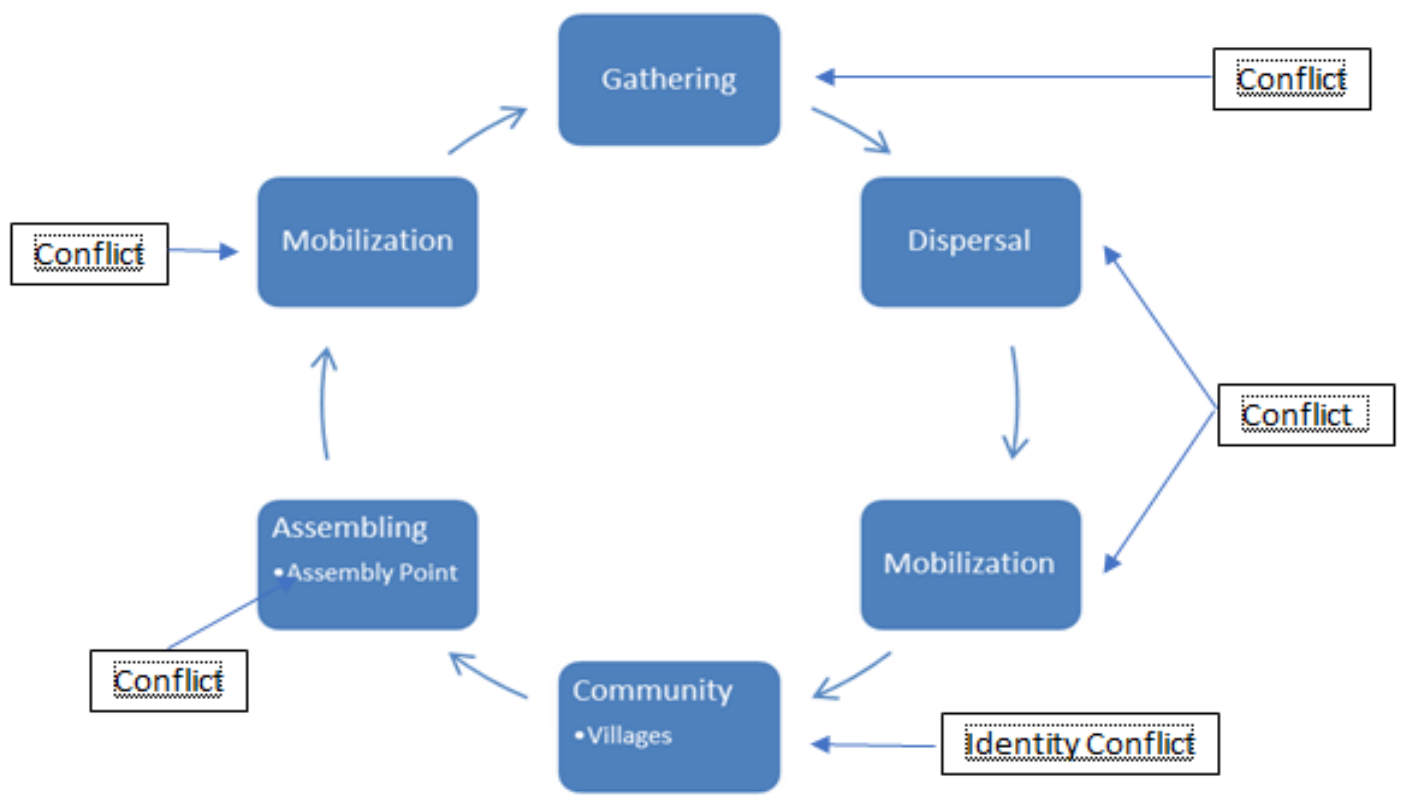

Figure 3. Conflict Point on Identity Conflict 
because of a recurring cycle that occurred in the context of crowds at Persib and Persija football matches. In figure 4 also explain how the police reaction in looking at a cycle starting from the community police stage is able to identify the problems that occur and this refers to the experience of the game before (incident driven policing), the taking of action that occurred any prohibition of supporter present (banning) to transfer of the venue of the match. At the assembling stage the police are able to do the naming until the security in the stage of mobilization to the gathering.

Arrangement of troops or power blocking occurred at the stadium location. This happens because of fears and prejudices that eventually form an incident driven policing paradigm.

\section{Summary}

The characteristics of crowds that occur in both stadiums of soccer matches in Bandung and Surakarta reflect the weakness of crowd's management as a venue for soccer matches that emphasize the security, regularity and regularity of the soccer audiences.

Excess capacity of the stadium; less professional ticketing problems; poorly arranged seating arrangement (demarcation sitting arrangement); various instructions (signage); and the weakness of various infrastructures (stadium safety features) is an indicator of weak crowd management in both Bandung and Solo venues as required international standardization.

Football match between Persija and Persib that lasted long time always colored by disorder (disorder), riots (violence) and the commotion between both Jakmania supporters and Viking Persib. Both supporters can be analogy as a group of hooliganism football supporters in the UK who have characteristics of violence, strength, irregularity and often referred to as trouble maker.

Polri's policy of not allowing one of the supporters present in the match between Persija and Persib is a policy to prevent riots between supporters who interfere with security and order, which historically the presence of both supporters in the club's second match is always a riot.

However, the absence of one of these supporter groups in Persija and Persib games still creates riots involving members of Jakmania and Viking groups. It can be concluded that the phenomenon of riot involving members of both supporters is not just a phenomenon of behavior and hooliganism attitude like the phenomenon that occurred in England.

The phenomenon of conflict involving the two supporter groups has crystallized into an identity conflict based on prejudice between the two groups. Subsequent forms of prejudice that also grew out of the state and the public have given rise to stereotypes that see Jakmania and Viking as monsterous that have the potential to pose a threat to security and order disorders, especially when the group is present in the arena of matches (Le Bon, 1896).

In accordance with the historical, philosophical, cultural and socioeconomic background that inspired the formation and founding of Jakmania and Viking, it can be concluded that initially both organizations were born to give support and love to Persija and Persib football club. But in its journey, organization and management especially Jakmania is more formal with hierarchical organizational structure and division of organizational tasks more struc- 
tured.

Such forms and organizational and management characteristics must have an influence on the behavior and attitudes of Jakmania members. The youth empowerment of marginal and highly heterogeneous community groups in Jakarta has aroused the spirit of militant Jakmania members coinciding in inspiration by community leaders who have a high fighting spirit. In contrast to the organization and management of Viking that is more informal and family spirit that is driven by a figure who puts forward the cultural and natural values based on the homogeneity of Sundanese culture.

Nevertheless, in its journey the spirit of cultural homogeneity has been acculturated with the values and spirit of the "Viking" foreign nation characterized by brave values, conquerors and loyalty, thus encouraging bobotoh to join the Viking supporters whose numbers are expanding, growing and growing from the grassroots.

Policing conducted by police agencies tend to be using the classical view developed by Le Bon (1896), which sees crowds as a threat to security and order so that policing action is more oriented towards the creation of security by stacking as much security forces in the arena and surroundings.

The approach of the incidentdriven policing model is oriented to incident driven policing (Weisburd, 2012) which puts forward repressive action against various forms of security and order threat. In the mindset of such policing, the police tend to take over the role and function of the crowd management that should be the responsibility of the organizer of football matches. An understanding of the importance of crowd management and crowd control by the event organizers is still very low, and rely on police roles.

Police's policies and strategies in crowd's management are based on standard, standardized and valid models for all security activities involving the crowd. Policing policies and strategies in handling crowds are often directly proportional to the estimated number of crowds at a particular event, thus implicating the size of the budget for security operations.

The empirical phenomenon of crowds in soccer event events has a significant difference compared with other sports performances or events. Moreover, Police Policy matches are set forth in the prevention and soft policing security plan, often paradoxically with field implementation that tends towards "reactive policing" or "incident driven policing".

The phenomenon of conflict between the two camps Jakmania and Viking supporters who have lasted for 5 years cannot be formulated "root of causes" it, so that efforts to prevent the riot supporters both camps are prohibited to attend by the police for one of the supporters in the match between Persija and Viking.

The conclusion of this dimension of research is that policing policies that prohibit the presence of one supporter in a match between Jakmania and Viking are more based on a very a priori "prejudice" motive for their behavior and attitude that tends to create riot, anarchism and chaos.

\section{Recommendation}

Football matches have evolved into industries around the world including Indonesia, so event organizers of football competitions must be professionally managed by prioritizing the 
importance of safety and security management for the realization of comfort, tranquility, security and order for soccer players, referees, and football lovers.

Therefore, the construction of the stadium as the arena of football matches in Indonesia should pay attention to the terms and conditions stipulated by FIFA stadium safety and security regulation. Next the event organizer of the football game in the future must have a professional crowd management and crowd control which includes three stages of strategy that is (1) pre-event strategy which includes road access; CCTV camera; lighting system; various signs and warnings; exit; emergency assistance and so on; (2) an event strategy that includes the place and waiting time for the soccer audiences; seating arrangement by demarcation; tickets and signs specified in accordance with instructions and security; (3) post-event strategy which includes the process of leaving the arena of the stadium regularly and smoothly according to the signs (signs) that have been determined; preparedness or alertness of security personnel and police in case of riots; and evacuation of emergencies by security and police in the event of security and order disturbances.

Therefore, in the future, event organizers or organizers of the football competition organizers are not only required to be professional in crowd management and crowd control, but the organizers must take full responsibility in realizing a safe and orderly football competition.

In this way, it can reduce the dominance of the police force and the overly dominant responsibility burden on the police institution. The practice of crowd management and crowd control applied in European countries has placed the Organizing Body as the sole responsibility for maintaining security and order.

It is necessary to formulate a regulation that governs the responsibilities and obligations of the organizers of the football competition and provides criminal sanctions for organizational organizations that are unable to realize the security and order of the implementation of football competitions. Also required is a regulation that regulates the development requirements of the stadium as defined by FIFA stadium safety and security regulations. Police policy to disallow one of Jakmania and Viking supporters to attend every match between Persija and Persib, is unlikely to prevent and solve the riot riots between the two supporter groups.

This phenomenon can be empirically evidenced by the continuing riot between members of the supporter group even if one of the supporter groups is not present in the arena of the game.

The root cause of the riots can be inferred because of the "prejudice" that has been internalized to the members of both camps. Therefore, it should formulate a strategy and approach that can bring peace, sportively habit and brotherhood values, so as to eliminate prolonged "prejudice" and spur the conflict between members of Jakmania and Viking. These strategic measures are not only the duty of the police, but should be the responsibility of various stakeholders related to the issue of football matches, such as local government, community leaders, religious leaders, responsible Jakmania and Viking organizers.

The effort to build trust in the level of awareness, peace and mutual 
respect is not easy, so it requires a sustainable effort to build a culture of sportsmanship in the football competition. For example, organizers of the Jakmania and Viking organizations should undertake ongoing coaching on the areas or locations where the supporters of Jakmania and Vikings are located. Police conduct guidance through "community policing" on Jakmania and Viking villages. Similarly, local governments, community and religious leaders are doing the same thing in preventing the ongoing conflict between the two supporters Jakmania and Viking groups.

The Jakmania and Viking organizations must reform their members because the unrest between the two members of the organization does not only occur in the arena of matches between Persija and Persib with the presence of both groups such as the phenomenon of hooliganism in the UK and European countries.

The riot action between members of the Jakmania and Viking support groups has evolved into an identity crisis, requiring the organization's serious and fundamental guidance on mental, behavior, attitudes and action in accordance with the sportsmanship values of football matches. The pattern of guidance to members of Jakmania and Viking should be done periodically, structured and professional so as to build a sense of "trust" of both Jakmania and Viking members.

The policing strategy that must be done must begin in the phase of community, which is the phase before the group stage of Jakmania supporters gather and head to the arena of the match (gathering phase). The preassembly phase can be done through community policing programs, especially on the power nodes of Jakmania and Viking groups.

Community policing activities are carried out jointly with both organizations, local government, community and religious leaders that militancy, fanaticism and prejudices that can cause unrest and tend to disrupt security and order in support of football matches between Persija and Persib, should be discontinued because it will harm the comfort and development of sports and football industry in Indonesia.

The community policing strategy is also done in the assembly phase where each member of Jakmania and Viking groups has started gathering to the arena. Policing strategy in this phase is also important to do policing as a process of convincing and providing understanding to Jakmania and Viking groups that orderliness and regularity are values that must be the culture of a nation that is mature, moral and religious.

The soft policing approach is important to build awareness, understanding and togetherness in realizing the spirit of sportsmanship and regularity. Policing strategy in the gathering phase is a phase in the arena where the role of police plays more as security support to the organizer of the game as the main responsibility with support by professional management of the crowd. In this way it has developed a sense of responsibility, maturity, professionalism and leadership of the match organizers as applied in developed countries in managing football matches. Thus, it can help to alleviate the task of the police that is so dominant with the orientation of the deployment of large troops, because it is always based on the assumption "should not underestimate" the police concern about the po- 
tential violence and riot that disturb security and order.

Policing strategy in the dispersal phase in which the dispersed audience began to leave the arena is an important phase of the organizers and fully assisted by the police to anticipate the chaos and riots. But with good and professional "management crowds" will reduce the police's concern in managing crowd control "because crowd control" is an inseparable part of crowd management."

Police's policies that are generally applicable to all activities involving the crowds need to be complemented by operational standards of procedures that are specific to the football game. This is because the empirical and conceptual phenomena of the crowd in soccer matches are very different from the crowd phenomenon in other sports games, music concerts, demonstrations and other events. Moreover, the phenomenon of hooliganism groups are very fanatical, solid and militant in support of certain football clubs.

Further Police must develop policies to require personnel to have the knowledge, strategies and tactics needed to handle the soccer crowds including the knowledge of crowd management and crowd control. " It is necessary to develop joint policy with relevant Institutions on the requirements of football stadium development as determined by FIFA International including the requirements of crowd management and crowd control.

"Police then need to take the initiative to establish a Joint policy in which Jakmania and Viking organizations and local governments should coach the mentors, morals, behaviors and attitudes of their group members in support of the love, professionalism and sportsmanship of the football clubs it supports.

This is very necessary to help the police no longer adopt a policy of prohibition for both Jakmania and Viking supporters to attend the match between Persija and Persib, as this form of prohibition can be counterproductive to the credibility of the police to maintain and enforce security and order.

\section{References}

Anderson, Benedict, (1983), Imagined Communities: Reflection on the Origin and Spread of Nationalism, London : Verso.

Berlonghi.A.E. (1994). The Special Event Risk Management Manual. Dana Point, CA:Berlonghi USA

Blumer, Herbert., (1968) Symbolic Interactionism: Perspective and Method. Los Angeles: University of California Press,.

Brown, Rupert, (2011), Prejudice: Its Social Psycology, New Jersey: Wiley-Blackwell..

C.Stott and G.Pearson. (2007). Football Hooliganism". Policing and the War on the "English Disease. London, Pennant Books.

Canetti, Elias, (1973), Crowds and Power, New York: Viking Press,

Castells, Manuel, (2000), Rise of the Network Society, New Jersey: Blackwell Publising.

Chrysnanda. DL, (2011), Kenapa Mereka Takut Dan Enggan Berurusan Dengan Polisi?: Sebuah Catatan Harian, Jakarta: YPKIK.

David Weisburd.et.al. (2008). The Effect of problem Oriented Policing on Crime and Disorder. The US Department of Justice, USA.

Le Bon, Gustav, (2002), The Crowd: A 
Study of The Popular Mind, New

York: Dover Publication,

McPhail, Clarke, (1997), Acting Together: The Social Organization of Crowds, Berlin : Walter de Gruyter GmbH.

Parks, Rogers B.(1981). Consumers as Coproducers of Public Services. Policy Studies Journal, USA.

Ritzer, Geoge, (2009), Contemporary Sociological Theory and Its Classical Roots: The Basic, McGrawHill,.

Sears, D.G., Freedman,J.L \& Peplau, L.A. 1994. Psychology Sosial. Jilid 2. Alih Bahasa:Michael Adriyanto. Jakarta :Erlangga

Sunarto, Kamanto., (2000), Pengantar Sosiologi Edisi Kedua. Jakarta: Lembaga Penerbit Fakultas Ekonomi Universitas Indonesia.

Tamara.D. Madensen and Johannes Knutsson (2011). Preventing Crowd Violence. Lynne Rienner Publishers, Boulder, Colorado, USA.

Voris, John, (2015), Civilian in Arms, Whitefish : Literacy Licensing.

Abbot, Je'anna Lanza and Morgan W.Geddie. (2001). Event and Venue Management: Minimizing Liability Through Effective Crowd Management Techniques.Journal of Event Management, USA.

Berlonghi.A.E. (1995). Understanding and Planning for Different Spectator Crowds. Safety Science.

Braiden.Chris. (1992). Enriching Traditional Police Roles. "Police Management: Issues and Perspectives. Washington, DC.: Police Executive Research Forum, USA

Goldstein, Herman. (1993), The New Policing: Confronting Complexity. National Institute of Justice,
Research in Brief. Washington DC, USA. Department of Juctice. Reprinted in Oliver, Wilard M., ed. (2000). Community Policing: Classical Reading, 71-80. Upper Saddle River, N.J.: Prentice Hall.

John M.Kenny et.al.(2001). Crowd Behavior, Crowd Control, and the Use of Non-lethal weapons.

Kari Sari (2009). Crowd Situations and Their Policing: From the Perspective of Finnish Police Officers. A case Study of Finnish Police Knowledge. Journal of Scandinavian Studies in Criminology and Crime Prevention

Utami, Sri, (2011), Hubungan Status Identitas dengan Self-Esteem Remaja (Studi Deskriptif Korelasi Pada Siswa Kelas XI SMA Negeri 2 Kota Bandung Tahun Ajaran 2010/2011), Skripsi, Bandung: Fakultas Ilmu Pendidikan, Universitas Pendidikan Indonesia.

Hamley, Katherine, Media Use In Identity Construction, www.aber.ac.uk/media/students/ klh9802.html April, 2001 